\title{
The relationship between knowledge and hypothermia first aid attitudes in mountain climbers
}

\author{
Mayang Dwi Setiyani ${ }^{1}$, Nurul Fatwati Fitriana ${ }^{2}$ \\ ${ }^{1,2}$ Faculty of Health Sciences, Muhammadiyah University Of Purwokerto
}

\begin{abstract}
ARTICLE INFO
Article history:

Received: August 9, 2020

Revised: August 20, 2020

Accepted: August 30, 2020

\section{Keywords:}

Hypothermia, climber

knowledge, first aid, attitude

ABSTRACT

Mountain climbing is an interesting and challenging activity, but it has high risks. There is a risk of harm that threat the body and safety during mountain climbing. One of the risks that can occur in mountain climbing is hypothermia which should be treated quickly and appropriately otherwise it can be lifethreatening. From the results of preliminary studies that have been conducted by researchers at the Mount Prau Basecamp. According to the Gunung Prau Basecamp guard in 2017 there were 4 cases of hypothermia per week, even in 2014 there was 1 case of a climber who died due to hypothermia. This case occurred because of the climber's lack of knowledge of doing first aid to victims who had hypothermia. In this case, the climber's knowledge and attitude about prevention and first aid when experiencing hypothermia are the most important factors. The aim of this study was to determine the correlation between climber's knowledge and hypothermia first aid attitudes on the mountain.The type of this research was quantitative research with the correlation study method and a cross-section approach. The population in this study were all climbers of Mount Prau Wonosobo with a sample of 333 respondents. The sampling technique used in this study was consecutive sampling. The data in this study were analyzed using the chi square statistical test.The results of this study were obtained from 333 respondents, 301 respondents (90.4\%) had good knowledge and 297 respondents $(89.2 \%)$ had good attitudes. Statistical analysis showed significant results with a p-value (0.0001) less than 0.05, thus H0 was rejected and $\mathrm{H} 1$ was accepted, which indicated that there was a relationship between the climber's knowledge and hypothermia first aid attitudes on the mountain. In conclusion Knowledge affects a person's attitude towards handling hypothermia. On condition that the knowledge is good, ensuingly the attitude in handling hypothermia will be good.
\end{abstract}

This work is licensed under a Creative Commons Attribution 4.0 International License.

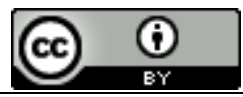

\footnotetext{
Corresponding Author:

Nurul Fatwati Fitriana

Medical Surgical of Nursing Departement

University Muhammadiyah Purwokerto

Email: nurulfatwati90@gmail.com
}

\section{INTRODUCTION}

Today climbing mountains is a trend among young people. The increase in the number of climbers is accompanied by an increase in the number of cases of death on the mountain. Most of the deaths on the mountains were caused by hypothermia. Between 2003 and 2013 more than 13,400 people died of hypothermia in the United States, according to the Centers for Disease Control and Prevention (CDC). In the United States about 1500 people die from primary hypothermia each year [1]. In Indonesia, from 2013 to 2015 at least 18 people died due to hypothermia while climbing [2]. According to data compiled by the National Search and Relief Agency, known as BASARNAS, in 2015-2019 the number of climbing accidents has increased. One type of accident that often lurks climbers and leads to death is hypothermia. In an accident that occurred in 2015, there were 12 climbing accidents that occurred which caused 2 climbers to die, 4 climbers were found 
sick, and 6 climbers were found safe. Meanwhile, in 2016, the number of climbing accidents increased to 15 cases which caused 7 climbers to die, 7 climbers were found injured, and one climber was found in good health. Whereas in 2017, the number of climbing accidents was the same as in 2016, namely 7 climbers died, 5 climbers were found sick, and 3 climbers were found healthy. And the number increased quite significantly in 2018, as many as 23 incidents occurred which caused 6 climbers to die, 4 climbers were declared missing, and 7 climbers were found sick. And at the beginning of 2019 there were 25 cases that occurred [3].

Mountain climbing is an activity that is interesting, exciting, challenging but high risk. Various hazards in outdoor activities are divided into two, namely subjective hazards and objective hazards. Subjective hazards are dangers caused by human factors, namely the climbers themselves such as underestimating nature, lack of mental, physical preparation, equipment, tools, skills, poor management in managing logistics, improper packing of goods, uncontrollable emotions, going in the entourage is too large, and there is a lack of knowledge about the causes of hypothermia. Objective hazards are hazards caused by natural factors, including earthquakes, volcanic activity, storms, rain, fog and landslides. Subjective hazards can be avoided by being prepared as well as possible, while objective hazards cannot be avoided but their consequences can be minimized. In general, most mountain climbing disasters occur due to human factors [4].

When climbing a mountain there are risks that are detrimental, threatening to the body and the safety of the soul, some of the risks that can occur when climbing on a mountain, including wounds, infections caused by the entry of germs through open wounds, poisoning of some gases found in the mountain or food that is found contains toxins, acute mountain sickness, hypoxia, hypothermia, lack of fluids in body cells, heat stroke, muscle cramps, and frost bite [5]. Some of the life-threatening risks when climbing on a mountain are as follows: First, Mountain Sickness occurs due to the body's inability to adapt to natural conditions in the mountains that are different from the lowlands, it is not uncommon for climbers to die from mountain sickness. Second, heat stroke (heat stroke) occurs when the patient is no longer able to expel excess heat so that the body temperature becomes too high and is dangerous for the patient's safety. Third, one of the effects of hypothermia is poor tissue oxygenation throughout the body caused by peripheral vasoconstriction, decreased myocardial contractility, and decreased oxygen release from hemoglobin to the tissues [6]. $20 \%-50 \%$ of the causes of death on the mountain are caused by hypothermia.

Hypothermia is a condition where the body temperature drops abnormally low below 35oC due to heat loss, which is a dangerous condition. Loss of body heat occurs in four ways: conduction, radiation, convection, and evaporation. The decrease in body temperature is categorized into three, namely: mild hypothermia (32$35^{\circ} \mathrm{C}$ ), moderate hypothermia $\left(28-32^{\circ} \mathrm{C}\right)$ and severe hypothermia (below $28^{\circ} \mathrm{C}$ ). Causes of hypothermia include environmental exposure, medical conditions such as sepsis, hypoglycemia, neuromuscular diseases, malnutrition, hypothyroidism, drugs and alcohol [7]. To avoid cases of hypothermia, you should start from consuming good and correct food, because food digestion is the main element that produces body heat. Digestion of food can produce calories that can be converted into energy. If a normal person needs 2000 calories per day, for mountain climbers it takes about 5000 calories because it is associated with strenuous and continuous activity. We can maintain body heat from the activities we do, at least assisted by clothes that dry quickly and do not get wet. Wet clothing can lose up to 90 percent of the insulation value (body heat insulation). The signs of someone having hypothermia are indeed difficult to detect for novice climbers if we do not know it, sometimes someone thinks that someone who is hypothermic is like a trance. This needs to be understood again for previous novice climbers. Thus it can readily respond to hypothermia and there will be no more cases that lead to death if climbers understand this [8].

The incidence of hypothermia can also be reduced by early recognition and treatment of hypothermia to oppose the deterioration of the patient's condition. Treatment should ideally be initiated in the prehospital setting and should focus on reducing heat loss, increasing cardiovascular stability, restoring fluid volume and reversing core cooling [9]. Lack of knowledge among climbers about hypothermia is also a cause of increasing cases of hypothermia. One of the myths about hypothermia among climbers is that the heat loss is much greater in the head than in any other part of the body. So that many climbers use hats or headgear to keep the head warm, but pay less attention to other parts of the body. This is not justified, because body heat is lost through all parts exposed to the cold environment. Expenditure of heat on the head of an adult is only about $10 \%$ of the other body parts [10]. The increase in the number of climbers who are at risk of increasing the incidence of hypothermia can actually be suppressed by providing appropriate treatment to sufferers. In this case, the climber's knowledge of prevention and first aid when experiencing hypothermia is the most important factor. Providing appropriate and fast action can reduce the risk of hypothermia and increase life expectancy for sufferers so that the death rate due to hypothermia can be reduced.

From the results of preliminary studies that have been conducted by researchers at the Mount Prau Basecamp. According to the Gunung Prau Basecamp guard in 2017 there were 4 cases of hypothermia per week, even in 2014 there was 1 case of a climber who died due to hypothermia. This case occurred because of the climber's lack of knowledge of doing first aid to victims who had hypothermia. In some of the climbers 
who were interviewed, most of them did not know the symptoms and the correct way of first aid for hypothermic victims. However, in April 2019, after the climber's check list system was implemented before climbing, cases of hypothermia decreased. But if during the rainy season, cases of hypothermia increase again. The total number of climbers per month is approximately 2000 climbers who climb Mount Prau. In this study, more emphasis is placed on the attitudes of climbers towards hypothermic first aid as shown in the questionnaire with climbers in general who have different backgrounds.

\section{RESEARCH METHOD}

This type of research used in this research is quantitative research. The method used is the correlation study with a cross-section approach. The population in this study were all climbers on Mount Prau Wonosobo, with an average number of 2000 climbers for 1 month. The sampling technique used consecutive sampling. The number of samples in this study were 333 respondents. The place and time of this research were carried out at Basecamp Mount Prau Wonosobo on December 25-31 2019. The instrument in this study used a questionnaire. The technique of collecting data is by filling out a questionnaire which is done by the respondents themselves.

\section{RESULTS AND DISCUSSIONS}

3.1. Characteristics of Respondents

Table 1. Characteristics of respondents $(n=333)$

\begin{tabular}{lcc}
\hline \multicolumn{1}{c}{ Characteristic } & Frequency & Percentage \\
\hline Respondent gender & 259 & $77,8 \%$ \\
$\quad$ Male & 74 & $22,2 \%$ \\
$\quad$ Female & & \\
Respondent Age & 42 & $12,6 \%$ \\
12-16 years & 270 & $81,1 \%$ \\
17-25 years & & \\
Respondent Education & 2 & $0,6 \%$ \\
$\quad$ Elementary School & 36 & $10,8 \%$ \\
Junior High School & 258 & $77,5 \%$ \\
Senior High School & & \\
Ascent to- & 192 & $57,7 \%$ \\
2-4 time & 141 & $42,3 \%$ \\
$\quad>4$ time & & \\
\hline
\end{tabular}

Based on table 1 it is known that the gender characteristics of the respondents, most of whom are male, are 259 respondents $(77.8 \%)$, the characteristics of the respondents are mostly 17-25 years old, namely 270 respondents $(81.1 \%$ ) because that age is productive age who climbs when there is a holiday and needs entertainment. The education level of respondents in this study were mostly high school graduates as many as 258 respondents $(77.5 \%$ ) because in Indonesia the minimum education is 12 years or equivalent to high school, and the climbing is done partly large 2-4 times as many as 192 respondents $(57.5 \%)$.

\subsection{Climber Knowledge and Attitude}

Table 2. Climber Knowledge and Attitude about Hypothermic First Aid on the Mountain

\begin{tabular}{lcc}
\hline \multicolumn{1}{c}{ Variable } & Frequency & Percentage \\
\hline Knowledge & & \\
Good & 301 & $90,4 \%$ \\
Enough & 30 & $9.0 \%$ \\
Less & 2 & $0,6 \%$ \\
Attitude & & \\
Good & 297 & $89,2 \%$ \\
Enough & 35 & $10,5 \%$ \\
Less & 1 & $0,3 \%$ \\
\hline
\end{tabular}

From table 2. it can be seen that most respondents have good knowledge of hypothermic first aid as many as 301 respondents $(90.4 \%)$. Most of the respondents had a good attitude towards hypothermic first aid as many as 297 respondents $(89.2 \%)$. 


\subsection{Climber Knowledge Relationship to Hypothermic First Aid Attitude on the Mountain}

Table 3. Climber Knowledge Relationship to Hypothermic First Aid Attitude on the Mountain

\begin{tabular}{lccccccccc}
\hline \multirow{2}{*}{ Knowledge } & \multicolumn{4}{c}{ Attitude } & \multicolumn{2}{c}{ Total } & \multicolumn{2}{c}{ p-value } \\
\cline { 2 - 8 } & \multicolumn{2}{c}{ Good } & \multicolumn{2}{c}{ Enough } & \multicolumn{2}{c}{ Less } & & \\
\cline { 2 - 8 } & $\mathrm{f}$ & $\%$ & $\mathrm{f}$ & $\%$ & $\mathrm{f}$ & $\%$ & $\mathrm{n}$ & $\%$ & \\
\hline Good & 285 & 94,7 & 16 & 5,3 & 0 & 0,0 & 301 & 100,0 & 0,0001 \\
Enough & 11 & 36,7 & 19 & 63,3 & 0 & 0,0 & 30 & 100,0 & \\
Less & 1 & 50,0 & 0 & 0,0 & 1 & 50,0 & 2 & 100,0 & \\
\hline
\end{tabular}

Based on table 3, it is known that the p-value of the research results shows a value of $<0.005$, which means that statistically there is a relationship between climber knowledge and hypothermic first aid attitudes on the mountain.

\subsection{Discussion}

Most of the respondents were male, as many as 259 respondents $(77.8 \%)$ this happened because when the research was carried out, most of the respondents who carried out the suspension were male. The results of this study are the same as research by Susilowati which states that $100 \%$ of climbers are male [11]. Mountain climbing is a sport with a high level of risk and requires more energy [12]. In addition to these factors, mental readiness when climbing must also be strong to face strenuous activities in nature and the threat of dangers that can occur at any time [13].

Based on the age characteristics of the respondents, most of them are aged 17-25 years, totaling 270 respondents $(81.1 \%)$. This is because at that age they are still able to climb and need new experiences or try something new. Respondents aged 12-16 years are accompanied by their parents in climbing activities so that it will be safer. The results of this study are the same as the research which states that at that age period is the productive and active age range where a person is able to think rationally and it is easy to capture knowledge and information. So that in that age range, the provision of knowledge during provisioning is easily absorbed.

Based on the education level of the respondents in this study, the majority were at the high school education level (SMA) as many as 258 respondents (77.5\%). This could be due to the fact that most of the respondents are in their late teens and in Indonesia the last education is at least 12 years old or equivalent to high school [14]. Sukamto's research states that $62 \%$ of climbers have a high school education. This is because intelligence affects the climber's knowledge more so that it is at a good level [15].

Based on the experience of most of the climbers 2-4 times as many as $192(57.7 \%)$, this is because climbers do have a hobby of sports. Most of them are of productive age, so they still need new experiences and are challenged to climb other mountains [16]. Research by Naldi states that most respondents have good behavior in handling hypothermia. This is due to the long experience of climbing, most of whom have at least 1 year of climbing experience [17]. Rapid behavior in handling hypothermia is obtained from experiences or incidents while climbing.

In the knowledge variable of climbers on hypothermic first aid, it is known that most respondents have good knowledge of 301 respondents $(90.4 \%)$. This indicates that the climber has good knowledge regarding hypothermic first aid. This can happen seeing that one of the factors affecting knowledge is the high level of education [18]. This can also be seen from the level of education of climbers, which shows that the majority of education is high school level. In accordance with the theory put forward by Notoatmodjo that education is one of the reasons for high knowledge. This is supported by research conducted by Sari which shows the results of research as many as 45 people (57\%) of 79 respondents are in good and sufficient ranges, the interpretation stated that almost all of the respondents are categorized as having good and sufficient knowledge about hypothermia when mountain climbing [19]. In the research questionnaire regarding the statement "hallucinations due to hypothermia can cause strange actions such as running around, undressing because of the heat", 173 out of 333 respondents answered incorrectly. Meanwhile, according to the theory put forward by Rab, people who experience hypothermia there is a suppression of the central nervous system which results in disruption of orientation in terms of time, place, people, and decreased consciousness [20].

In the climber's attitude variable towards hypothermic first aid, there were 297 respondents $(89.2 \%)$ who had good attitude, 35 respondents $(10.5 \%)$ had sufficient attitudes, and 1 respondent $(0.3 \%)$ had poor attitudes. Attitude is a kind of readiness to react to an object in certain ways. Readiness in this definition is interpreted as a potential tendency to react when the individual is exposed to a stimulus or stimulus that requires a response. So, it can be said that the attitude as a response, this is based on the evaluation process in the individual which will ultimately give conclusions in the form of values for stimuli in the form of good or bad, positive or negative, pleasant or unpleasant, like it or not, which then crystallize or not as a potential reaction to the object [21]. This is supported by research conducted by Romadhona which shows the results of the research of 24 
respondents (54.5\%) having good and sufficient knowledge with a good attitude [22]. Good climber knowledge and good attitude due to the climber's experience of hypothermia.

In a study conducted, the average ascent that has been done by the respondents is more than 2 times. In the research questionnaire the statement "I can give warm drinks to climbers who are not aware because of hypothermia" 175 respondents out of 333 respondents answered agree and strongly agree. Meanwhile, according to the theory put forward providing warm drinks containing sugar can only be given to climbers who are conscious and easy to swallow. In the statement "I can use a heating lamp to warm the body of a climber who is affected by hypothermia" 206 out of 333 respondents answered agree and strongly agree. Whereas in the statement "I have to compress a hiker who is exposed to hypothermia with a bottle filled with hot water in the head, neck, chest, and stomach area can handle hypothermia" 262 respondents out of 333 respondents answered agree and strongly agree. Even though according to the theory put forward by Alton, if a climber who is hypothermic is in a shivering state, don't stop it by applying heat such as a member of a bottle filled with hot water or a heating bag and heating lamp. Because shivering will generate body heat and re-warm climbers who experience mild hypothermia.

The results showed that there was a relationship between the knowledge of climbers and hypothermic first aid attitudes on the mountain. This can be said by the authors seeing the calculation of SPSS data which shows a p-value $<0.005$, which means that statistically there is a relationship between climber knowledge and hypothermic first aid attitudes on the mountain. Most climbers have a good knowledge of hypothermia first aid. This could be due to the education of climbers who mostly completed high school education (SMA) as many as 301 respondents $(90.4 \%)$. Education as we know it is one of the mediators for someone to gain knowledge or insight. According to the study, in his research said that the higher a person's education, the attitude he shows towards hypothermia is also good. This theory strengthens the research conducted by researchers that the climber's knowledge of hypothermic first aid is one of the factors influencing the climber's attitude towards hypothermic first aid. It is very likely that climbers with good knowledge have a good attitude towards hypothermic first aid [23].

Age is one of the reasons for the amount of information that has been obtained. According to the data that the researchers found, the majority of climbers have an age range of 17-25 years as many as 270 respondents $(81.1 \%)$. Age $17-25$ years is the age of late adolescence. This age group is more curious about many things, thus enabling the respondents to actively seek information from various sources. For this reason, this age will have a lot of experience and influence on individual attitudes [24]. Attitudes of climbers about hypothermia have a good attitude as many as 297 respondents $(89.2 \%)$.

Attitude of climbers to hypothermic first aid is influenced by how climbers interpret hypothermic first aid. It is this interpretation that causes good, insufficient, or a lack of hypothermic first aid attitudes. This interpretation is influenced by one of which is the climber's knowledge of hypothermic first aid. Knowledge of course can also influence the interpretation of the climber's mindset towards hypothermic first aid. Climbers' knowledge of hypothermic first aid on the mountain is quite good, namely 301 respondents (90.4\%). Suggests that attitude involves some knowledge about something. However, an essential aspect of attitude is the presence of feelings or emotions, a tendency towards actions related to knowledge. Attitude involves knowledge about something, including the situation [25].

The situation here can be described as an object that will ultimately affect feelings or emotions and then allow a reaction or response or tendency to act. Thus, knowledge about something is the beginning that affects an attitude that may lead to an action. The difference in this study with previous research conducted is that it emphasizes more on the hypothermic first aid points shown in the research questionnaire and in this study respondents were also taken from climbers in general who have different backgrounds. From the above conclusions, it can be concluded that knowledge will affect a person's attitude towards handling hypothermia. If the knowledge is good, then the attitude in handling hypothermia will be good. So that in this study there is a relationship between the climber's knowledge of hypothermic first aid attitudes on the mountain [26].

\section{CONCLUSION}

The characteristics of the respondents in this study can be said to be dominated by men as many as 259 respondents $(77.8 \%)$, most of the respondents aged $17-25$ years were 270 respondents $(81.1 \%)$, the education level of the respondents in this study was partly Most are high school graduates as many as 258 respondents (77.5\%), and most of the climbing experiences that have been done by climbers are 2-4 times as many as 192 respondents $(57.7 \%)$. Knowledge of hypothermic first aid climbers is known that 301 respondents $(90.4 \%)$ have good knowledge, 30 respondents $(9.0 \%)$ have sufficient knowledge, and 2 respondents $(0.6 \%)$ have less knowledge. Attitude of climbers towards hypothermic first aid is known that 297 respondents (89.2\%) have a good attitude, 35 respondents $(10.5 \%)$ have a fairly good attitude, and 1 respondent $(0.3 \%)$ has a poor attitude. Well, the results showed that there was a relationship between the knowledge of climbers and the attitude of hypothermic first aid on the mountain with a p-value. 


\section{REFERENCES}

[1] D. Brown, "Accidental Hypothermia.," N Engl J Med, vol. 367, no. 20, pp. 1930-8, 2012.

[2] Nurmansah, "40 Orang Pendaki Lebih Hilang dan Meninggal di Gunung Indonesia dalam 2 Tahun," 2015. [Online]. Available: www.yes-outdoor.com. [Accessed 23 Agustus 2019].

[3] BASARNAS, "Angka Kecelakaan Pendakian . Jakarta," 2019. [Online]. Available: https://BASARNAS.go.id. [Accessed 10 September 2019].

[4] C. Wijaya and W. Harry, Rekam Jejak Pendakian Ke 44 Gunung di Nusantara, Yogyakarta: ANDI, 2011.

[5] . H. Agustin, Pedoman Teknik Olahraga Alam Bebas, Surabaya: Matrapala, 2012.

[6] R. Gerecht, "Acidosis and Coagulopathy Create A Deadly Cycle for Trauma Patients," JEMS, vol. 39, no. 4, pp. 56-60, 2014.

[7] D. U. Silverthorn, Fisiologi Manusia : Sebuah Pendekatan Terintegrasi Edisi 6, Jakarta: EGC, 2014.

[8] I. Ikhwan, "Kampanye Tanggap Hipotermia Bagi Pendaki di Kawasan Taman Nasional Gunung Gede Pangrango," Universitas Telkom, Bandung, 2015.

[9] G. Giesbrecht, "Prehospital Management of Hypothermia," Elseiver. JINJ, vol. 16, p. 7480, 2017.

[10] Alton, Pertolongan Pertama Edisi Kelima, Jakarta: Penerbit Erlangga, 2011.

[11] T. Susilowati, "Hubungan Tingkat Pengetahuan dengan Perilaku Penanganan Gawat Darurat Hipotermi pada Pendaki Gunung di Organisasi Primapala Ampel Kabupaten Boyolali," Jurnal Ners dan Kebidanan, vol. 7, pp. 037-043, 2020.

[12] T. Susilo, Siap Mendaki : Panduan Dasar Kegiatan Pendakian, Bandung, 2012.

[13] Kholili, "Persiapan Fisik Dalam Pendakian Gunung Sindoro.," Universitas Wahid Hasyim, Semarang, 2018.

[14] Kemendikbud, "Kemdikbud Upayakan Wajib Belajar 12 Tahun Melalui PIP," 2012. [Online]. Available: https://psmk.kemdikbud.go.id. . [Accessed 2 Juni 2020].

[15] F. I. Sukamto, "Pengetahuan Tentang Penanganan Hipotermi pada Pendaki Gunung di Wana Wisata Cemoro Sewu, Gunung Lawu, Magetan," Universitas Muhammadiyah Ponorogo, Magetan, 2019.

[16] Rosana, "Hidupmu Bakal Berubah Kalau Kamu Sudah Pernah Coba Naik Gunung," 2016. [Online]. Available: https://www.adventuretravel.co.id. . [Accessed 15 Juni 2020].

[17] Y. Naldi, S. Atik and P. Purnomo, "Hubungan Pengetahuan Hipotermi dengan Perilaku Penanganan Awal Hipotermi pada Mahasiswa Pecinta Alam di Unswagati dan IAIN Syekh Nurjati Kota Cirebon. FK Universitas Swadaya Gunung Jati," Jurnal Kesehatan dan Kedokteran Tunas Medika, 2018.

[18] Notoadmojo, Promosi Kesehatan dan Perilaku Kesehatan, Jakarta: Rineka Cipta, 2012.

[19] Sari, "Gambaran Pengetahuan Mahasiswa Pecinta Alam Universitas Pendidikan Indonesia (MAPALA UPI) Tentang Hipotermia Saat Pendakian. Artikel Ilmiah.," Universitas Pendidikan Indonesia, Bandung, 2018.

[20] Rab, Agenda Gawat Darurat (Critical Care) Jilid 3, Bandung: Penerbit PT. Alumni, 2012.

[21] M. S. Tenrie, "Studi Korelasional antara Kompensasi dan Sikap Guru Terhadap Tugas dengan Disiplin Kerja Guru, Program Pascasarjana Magister Studi Islam Konsentrasi Manajemen Pendidikan," UNISMA, Bekasi, 2005.

[22] T. R. Romadhona, "Hubungan Pengetahuan dengan Sikap Pendaki tentang Pertolongan Pertama pada Kejadian Hipotermi di Wisata Cemoro Sewu, Kawasan Gunung Lawu, Kabupaten Magetan," Universitas Muhammadiyah Ponorogo, Semarang, 2018.

[23] C. Triwibowo and M. E. Puspahandi, Pengetahuan Dasar Ilmu Kesehatan Masyarakat, Yogyakarta: Medikal Book, 2015

[24] K. Z. Putro, "Memahami Ciri dan Tugas Perkembangan Masa Remaja," Jurnal Aplikasi Ilmu-ilmu Agama, vol. 17, no. 1, 2017.

[25] Ellis and S. Robert, Educational Pyschology: a Problem Approach, New York: Van Nostrard Co, 2012 .

[26] Kustina and S. Dewi , "Hubungan Pengetahuan Tentang Hipotermia Terhadap Praktik Penanganan Hipotermia pada Mahasiswa Pecinta Alam (MAPALA)," Universitas Muhammadiyah Semarang, Semarang, 2017. 